\title{
Commentary: Hepatitis: A way to make organ donation go viral?
}

\author{
Katrien Vandendriessche, MD, ${ }^{\mathrm{a}}$ Frederik Nevens, $\mathrm{MD}, \mathrm{PhD},{ }^{\mathrm{b}}$ Johan Van Cleemput, $\mathrm{MD}, \mathrm{PhD}$, \\ Dirk Van Raemdonck, MD, $\mathrm{PhD},{ }^{\mathrm{d}}$ and Filip Rega, $\mathrm{MD}, \mathrm{PhD}^{\mathrm{a}}$
}

\footnotetext{
From the Departments of a Cardiac Surgery, ${ }^{\mathrm{b}}$ Gastroenterology and Hepatology, ${ }^{\mathrm{c}}$ Cardiology, and ${ }^{\mathrm{d}}$ Thoracic Surgery, University Hospitals Leuven, Belgium.

Disclosures: Authors have nothing to disclose with regard to commercial support.

Received for publication Feb 22, 2019; revisions received Feb 22, 2019; accepted for publication Feb 22, 2019; available ahead of print June 10, 2019.

Address for reprints: Filip Rega, MD, PhD, Department of Cardiac Surgery, University Hospitals, Gasthuisberg Herestraat 49 B-3000, Leuven, Belgium (E-mail: filip.rega@uzleuven.be).

J Thorac Cardiovasc Surg 2019;158:554-5

$0022-5223 / \$ 36.00$

Copyright $(2019$ by The American Association for Thoracic Surgery

https://doi.org/10.1016/j.jtcvs.2019.02.141
}

In 2006, a YouTube video showed Juan Mann on the street, holding a sign: "Free Hugs." After initial hesitation, people chose to embrace this total stranger, enjoying the warmth of the gesture. Some 78,000,000 views later, this viral video of a random act of kindness represents the launch of a global social movement, the "Free Hugs Campaign."

This exponential increase in numbers stands in stark contrast with the statistics of a different fundamental act of kindness: organ donation. The scarcity of organ availability and the mismatch with the high organ demand remain significant. Use of hepatitis virus-infected organ donors is a controversial, yet rapidly evolving area in the quest for strategies to expand the donor pool.

The article by Radzi and co-workers ${ }^{2}$ represents the first article to describe the outcome of pediatric cardiac transplantation of hepatitis $B$ virus (HBV) or hepatitis $C$ virus (HCV)-infected donors in seronegative recipients. Of all transplant recipients in the United Network for Organ Sharing database from June 2008 to June 2015, only 12 cases were found. In the same database, 2203 potential yet unused donors for pediatric thoracic transplantation were identified. Although this number seems high, it does underline the potential this specific donor category has to offer.

By using propensity score models, the outcomes of the $\mathrm{HCV}$ - and hepatitis B virus core antibody (HBVcAB-) recipients with $\mathrm{HCV}+$ or $\mathrm{HBVcAB}+$ donors were compared with $\mathrm{HCV}$ - and $\mathrm{HBV} \mathrm{AB}$ - recipients and donors. For the 3 recipients of $\mathrm{HCV}+$ donor hearts, post-transplant graft 5year survival was similar to that of recipients of HCV- donors $(\mathrm{n}=3$ vs $\mathrm{n}=9 ; 67 \%$ vs $88 \%, P=.44)$, with 1 death due to respiratory failure. Nine $\mathrm{HBVcAB}+$ donor hearts were transplanted in $\mathrm{HBV} \mathrm{CAB}-$ and $\mathrm{HBsAg}$ - (hepatitis B surface antigen negative) recipients. For these patients, post-transplant 5-year graft survival was similar to that of failure. RNA.$+^{3}$

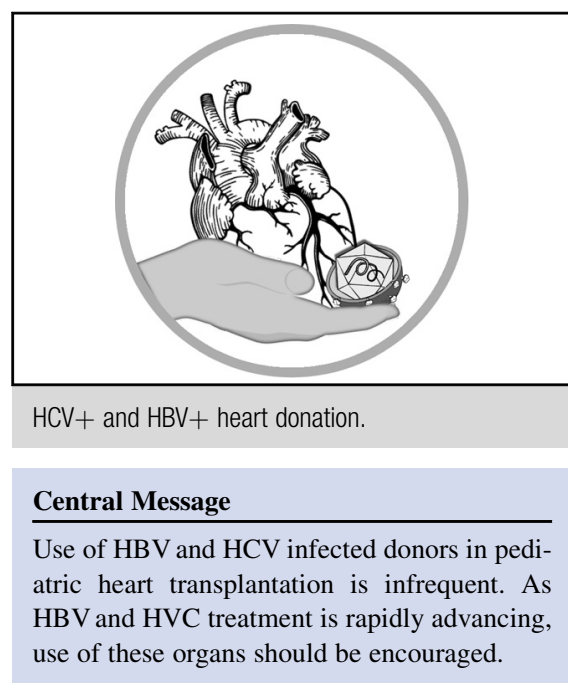

See Article page 548 .

recipients with $\mathrm{HBVcAB}$ - donors $(\mathrm{n}=9$ vs $\mathrm{n}=27 ; 87 \%$ vs $91 \%, P=.81$ ), with 1 death due to multiple system organ

Without a doubt, it is important to use consistent and correct terminology regarding the definition of an " $\mathrm{HCV}$ positive donor." Positive serology only indicates contact with the virus. Transmission occurs only if the donor is $\mathrm{HCV}$

For liver transplantation using $\mathrm{HCV}+$ donors, there is a risk of rapid progression to cirrhosis and fibrotic cholestatic hepatitis: a rare but lethal complication. Fortunately, the advent of direct-acting antiviral agents has drastically changed the landscape of hepatitis $\mathrm{C}$ treatment. The cure rate is approximately $100 \%$, even in patients under immunosuppression.

In this article, no data were available on antiviral therapy. However, for children aged less than 12 years, there are no Food and Drug Administration-approved direct-acting antiviral agents, and for adolescent children aged 12 years and more, only sofosbuvir/ledipasvir and sofosbuvir plus ribavirin are approved. ${ }^{4}$ Ten of the 12 cases reported by Radzi and co-workers ${ }^{2}$ were children aged less than 12 years.

Regarding the use of $\mathrm{HBVcAB}+$ donors, White and colleagues $^{5}$ found only 1 case of $\mathrm{HBV}$ transmission to an HBVsAg- heart recipient who did not receive prophylaxis of 122 adult heart/heart-lung transplants reported in the 
published literature involving $\mathrm{HBVcAB}+$ donors. However, there is no literature on the use of $\mathrm{HBVcAB}+$ thoracic donor organs in children. In adults, the risk of transmission is rather low if $\mathrm{HBV}$ vaccination has been completed before transplantation. If contamination occurs, effective antiviral treatment exists. ${ }^{6}$ In this study by Radzi and colleagues, ${ }^{2}$ the recipients of all $\mathrm{HBVcAB}+$ donor hearts were 6 months or older. Vaccination status, however, was not provided in the United Network for Organ Sharing database.

For the first time, Radzi and co-workers ${ }^{2}$ shed light on the use of $\mathrm{HCV}$ and $\mathrm{HBV}$-infected donors in pediatric heart transplantation. Although limited by size, the 5-year graft survival is promising. Given the rapid advancements in $\mathrm{HCV}$ and HBV treatment and the pertinent organ shortage, systematic use of these organs should be encouraged.

\section{References}

1. Free Hugs Campaign. Available at: https://en.wikipedia.org/wiki/Free_Hugs_ Campaign. Accessed February 15, 2019.

2. Radzi Y, Farrukh Shezad M, Danziger-Isakov L, Moralis DLS, Zafar F. Using hepatitis $\mathrm{C}$ and $\mathrm{B}$ virus-infected donor organs for pediatric heart transplantation. $J$ Thorac Cardiovasc Surg. 2019;158:548-53.

3. Levitsky J, Formica RN, Bloom RD, Friedman J, Goldberg D, Hall S, et al. The American Society of Transplantation consensus conference on the use of hepatitis C viremic donors in solid organ transplantation. Am J Transplant. 2017;17: 2790-802.

4. Vermehren J, Park JS, Jacobson IM, Zeuzem S. Challenges and perspectives of direct antivirals for the treatment of hepatitis C virus infection. J Hepatol. 2018; 69:1178-87.

5. White SL, Rawlinson W, Boan P, Sheppeard V, Wong G, Waller K, et al. Infectious disease transmission in solid organ transplantation: donor evaluation, recipient risk, and outcomes of transmission. Transpl Direct. 2018;4:1-91.

6. Huprikar S, Ahn J, Koval C, Lease ED, Pillai A, Doucette KE, et al. Solid organ transplantation from hepatitis B virus-positive donors: consensus guidelines for recipient management. Am J Transplant. 2015;15:1162-72. 